\title{
PENDUGAAN UMUR SIMPAN JELLY KELOR INSTAN DENGAN METODE ACCELERATED SHELF LIFE TEST (ASLT) MODEL PENDEKATAN KADAR AIR KRITIS
}

\author{
Mulia Winirsya Apriliyanti ${ }^{*}$, Annisa Nurdihati, M. Ardiyansyah \\ Prodi Teknologi Industri Pangan, Politeknik Negeri Jember \\ Email: mulia_apriliyanti@polije.ac.id
}

\begin{abstract}
ABSTRAK
Daun kelor merupakan tanaman yang kaya akan manfaat, utamanya bagi ibu menyusui dan anak dalam masa pertumbuhan. Jelly kelor instan adalah salah satu diversifikasi produk berbasis daun kelor. Penelitian ini bertujuan untuk memperkirakan umur simpan produk jelly kelor instan, sehingga dapat mengetahui perhitungan umur simpan secara akurat dan sesuai dengan umur simpan produk pangan yang sebenarnya. Pendugaan umur simpan pada produk makanan dan minuman instan dapat menggunakan metode ASLT (accelerated shelf life testing) model kadar air kritis berdasarkan persamaan Labuza. Tahapan dilakukan dengan melakukan kontrol lingkungan penyimpanan dan mempercepat reaksi penyebab kerusakan pada produk. Penyimpanan dilakukan menggunakan kemasan PP (polypropylene) dengan ketebalan $0,03 \mathrm{~mm}$ yang disimpan pada suhu ruang $25^{\circ} \mathrm{C}, 27^{\circ} \mathrm{C}$ dan $30^{\circ} \mathrm{C}$. Penelitian ini menghasilkan pendugaan umur simpan 789 hari pada suhu penyimpanan $25^{\circ} \mathrm{C}, 701$ hari pada suhu penyimpanan $27^{\circ} \mathrm{C}$ dan 589 hari pada suhu penyimpanan $30^{\circ} \mathrm{C}$.
\end{abstract}

Kata kunci: jelly kelor instan, umur simpan, metode kadar air kritis

\section{ABSTRACT}

Moringa leaves are a plant that is rich in benefits, especially for nursing mothers and children in their infancy. Instant Moringa Jelly is one of the diversification of Moringa leaf based products. This study aims to estimate the shelf life of instant Moringa jelly products, so as to provide an accurate shelf life calculation results and in accordance with the actual shelf life of food products. Estimating the shelf life of instant food products can be done using the ASLT (accelerated shelf life testing) method of the critical water content model calculated based on the Labuza equation. Stages are carried out by controlling the storage environment so that it can accelerate reactions that cause damage to the product. Storage is carried out using a PP (polypropylene) thickness of $0.03 \mathrm{~mm}$ at room temperature of $25^{\circ} \mathrm{C}, 27^{\circ} \mathrm{C}$ and $30^{\circ} \mathrm{C}$. This research resulted in an estimation of shelf life of 789 days at temperature storage's of $25^{\circ} \mathrm{C}, 701$ days at temperature storage's of $27^{\circ} \mathrm{C}$ and 589 days at temperature storage's of $30^{\circ} \mathrm{C}$.

Keywords: moringa jelly, instant jelly, shelf life, critical water content method

\section{PENDAHULUAN}

Kelor merupakan tanaman perdu yang kaya akan manfaat dan zat gizi. Bagian daun kelor memiliki banyak zat gizi yang baik dikonsumsi ibu menyusui untuk memperlancar keluarnya ASI (Prihayati et al., 2014). Daun kelor mengandung asam folat yang baik untuk dikonsumsi ibu hamil sebagai koenzim pada sistesis pirimidin dalam sistem DNA (deoxyribo

nucleic acid) (Tangkilisan dan Rumbajan, 2002). Asam folat juga diperlukan dalam pembentukan sel darah merah (Saptyasih et al., 2016) dan pertumbuhan anak (Krisnadi, 2015). Daun ini juga mengandung asam amino yang berupa asam glutamat, asam aspartat, alanin, 
methionin, leusin, isoleusin, lisin, histidin, arginin, triftopan, fenilalanin, valin, dan sistein (Simbolan et al., 2007). Asam amino dapat membantu proses pertumbuhan dalam tubuh dan memperbaiki jaringan tubuh.

Jelly kelor instan merupakan diversifikasi produk olahan berbasis kelor (Ningulan, 2018) dengan komposisi adalah $0,5 \%$ tepung daun kelor; $1,25 \%$ karagenan dan 1,25\% konjak. Hal-hal berkaitan dengan pangan telah diatur dalam Undangundang No. 7 tahun 1996 pasal 1 dan Peraturan Pemerintah No. 69 tahun 1999 pasal 2, disebutkan bahwa tanggal kadaluwarsa (expired date) wajib dicantumkan pada label kemasan suatu produk. Pencantuman tersebut dimaksudkan untuk memberi informasi kepada konsumen mengenai batas waktu produk pangan baik dikonsumsi (Hasany et al., 2017).

Penentuan tanggal kadaluarsa dapat dilakukan dengan cara menduga umur simpan suatu produk. Metode yang dapat digunakan dalam pendugaan umur simpan untuk produk-produk instan seperti jelly kelor instan adalah ASLT Accelerated (Shelf Life Test) dengan model kadar air kritis, yaitu melakukan percepatan reaksi sehingga produk dapat mengalami kerusakan dalam waktu lebih singkat (Arpah, 2001). Penelitian ini bertujuan untuk memperkirakan umur simpan jelly kelor instan dengan perhitungan menggunakan metode Accelerated Shelf Life Test (ASLT) model kadar air kritis sehingga diperoleh hasil perhitungan pendugaan umur simpan yang tepat dan akurat sesuai umur simpan produk pangan yang sebenarnya.

\section{METODE}

\section{Lokasi dan Waktu}

Penelitian dilakukan di Laboratorium Pengolahan Pangan dan Laboratorium Analisis, Jurusan Teknologi Pertanian Politeknik Negeri Jember pada bulan JuniAgustus 2019.

\section{Tahapan Penelitian}

1. Penentuan Kadar Air Awal (Mi)

Cawan petri kosong dibersihkan dan dikeringkan dalam oven dengan suhu \pm $105^{\circ} \mathrm{C}$ selama 1 jam, selanjutnya cawan dimasukkan dalam desikator selama kurang lebih 15 menit hingga beratnya konstan dan ditimbang (W1). Sampel sebanyak $2 \mathrm{~g}$ diletakkan dalam cawan petri yang telah konstan dan dimasukkan dalam oven pengering bersuhu $70^{\circ} \mathrm{C}$ selama 5 jam atau hingga mencapai bobot konstan. Cawan petri yang berisi sampel dimasukkan dan didinginkan dalam desikator kemudian ditimbang (W3). Kadar air awal dihitung dengan rumus:

$$
M i=\frac{(W 2)-(W 3-W 1) g H 2 O}{(W 3-W 1) \text { gpadat }}
$$

\section{Penentuan Kadar Air Kritis (Mc)}

Kadar air kritis adalah kadar air dimana jelly kelor instan telah membentuk gumpalan. Produk disimpan pada suhu $30^{\circ} \mathrm{C}$ dengan Aw 0,61 kemudian produk diamati setiap 24 jam hingga mencapai tingkat penggumpalan tertentu (Anom dan Komang, 2008). Skala nilai sensoris yang digunakan untuk tingkat penggumpalan adalah sangat menggumpal (1); menggumpal (2); agak menggumpal (3); netral (4); agak tidak menggumpal (5); tidak menggumpal (6); dan sangat tidak menggumpal (7). Produk yang telah mencapai skala 'netral' selanjutnya dianalisa kadar airnya.

\section{Kadar Air kesetimbangan (Me)}

Larutan garam jenuh pada Tabel 1 dipersiapkan terlebih dahulu. Sampel (jelly kelor instan yang telah dikemas) ditimbang beratnya. Sampel diletakan didalam toples tanpa menyentuh larutan garam jenuh. Selama penyimpanan sampel ditimbang secara periodik hingga mencapai berat konstan. Kondisi konstan dicapai apabila selisih penurunan atau kenaikan bobot produk pada 3 kali penimbangan tidak melebihi $2 \mathrm{mg} / \mathrm{g}$ pada penyimpanan $\mathrm{RH}$ dibawah $90 \%$ dan tidak melebihi $10 \mathrm{mg} / \mathrm{g}$ pada penyimpanan $\mathrm{RH}$ diatas $90 \%$. 
Apabila telah dicapai berat konstan pada sampel, maka dilakukan analisa kadar air (Anom dan Komang, 2008).

Tabel 1. Komposisi Jumlah Garam (g) dengan Jumlah Air (ml) dalam Pembuatan Garam Jenuh

\begin{tabular}{cccc}
\hline Garam Jenuh & Aw & Jumlah Garam (gr) & Jumlah Air (ml) \\
\hline $\mathrm{NaOH}$ & 0,06 & 150 & 85 \\
$\mathrm{MgCl}_{2}$ & 0,32 & 200 & 25 \\
$\mathrm{NaCl}$ & 0,75 & 200 & 60 \\
$\mathrm{KCl}$ & 0,84 & 200 & 80 \\
\hline
\end{tabular}

Sumber: Puji dan Arpah (2003)

\section{Slope Kurva Isotermik (b)}

Slope kurva isotermis diperoleh dengan cara mengambarkan hubungan antara kadar air kesetimbangan sampel dengan aktivitas air (Aw) ruang tempat penyimpanan (toples yang berisi garam jenuh (Anom dan Komang, 2008 dengan modifikasi)).

\section{Berat Kering Produk (Ws)}

Berat kering produk merupakan hasil kali berat sampel awal produk dikalikan dengan total padatan (Puji dan Arpah, 2003).

\section{Tekanan uap air jenuh (Po)}

Penentuan tekanan uap air jenuh dapat dilihat dengan menggunakan tabel hubungan antara aktivitas air dengan suhu.

\section{Penentuan umur simpan}

Semua parameter, yaitu Mi, Mc, Me, $\mathrm{k} / \mathrm{x}, \mathrm{Po}, \mathrm{b}, \mathrm{A}$ dan Ws yang telah diukur dan ditetapkan dari tahap sebelumnya diintegrasikan ke dalam persamaan Labuza berikut ini:

Keterangan:

$$
\theta=\frac{\ln \frac{(M e-M i)}{(M e-M c)}}{\frac{k}{x}\left(\frac{A}{W S}\right) \frac{P o}{b}}
$$

$\theta \quad=$ Waktu perkiraan umur simpan (hari)

$\mathrm{Mi}=$ Kadar air awal produk $\left(\mathrm{g} \mathrm{H}_{2} \mathrm{O} / \mathrm{g}\right.$ padatan)
$\mathrm{Me}=$ Kadar air keseimbangan produk ( $\mathrm{g}$ $\mathrm{H}_{2} \mathrm{O} / \mathrm{g}$ padatan)

$\mathrm{Mc}=$ Kadar air kritis $\left(\mathrm{g} \mathrm{H}_{2} \mathrm{O} / \mathrm{g}\right.$ padatan $)$

$k / x=$ Permeabilitas uap air kemasan $\left(\mathrm{g} / \mathrm{m}^{2}\right.$.hari. $\left.\mathrm{mmHg}\right)$

A $=$ Luas permukaan kemasan $\left(\mathrm{m}^{2}\right)$

$\mathrm{Ws}=$ Berat kering produk dalam kemasan (g padatan)

Po $=$ tekanan uap jenuh $(\mathrm{mmHg})$

$\mathrm{b} \quad=$ Slope kurva sorpsi isotermis

\section{HASIL dan PEMBAHASAN}

\section{Parameter Utama Kerusakan Produk Jelly Kelor Instan}

Jelly kelor instan merupakan hasil produk diversifikasi berupa serbuk yang diracik dari tepung daun kelor, karagenan, dan konjak. Serbuk termasuk dalam jenis produk kering, parameter utama kerusakan pada produk kering adalah tekstur atau kenampakannya. Kerusakan ini disebabkan terjadinya perubahan kadar air produk yang secara visual ditandai dengan perubahan wujud bubuk membentuk gumpalan. Pengamatan dilakukan secara visual dengan cara menyimpan produk tanpa kemasan di ruangan terbuka sampai produk tersebut mengalami kerusakan. Berdasarkan lama penyimpanannya, perubahan wujud secara visual ditunjukkan pada Tabel 2. 
Tabel 2. Pengamatan Kenampakan Jelly Kelor Instan Secara Visual

\begin{tabular}{|c|c|}
\hline $\begin{array}{l}\text { Lama Penyimpanan } \\
\text { (hari) }\end{array}$ & Kenampakan Fisik \\
\hline 0 & Halus dan tidak ada butiran, jika diaduk tidak berat. \\
\hline 2 & $\begin{array}{l}\text { Terbentuk } 3 \text { butiran kecil, jika di sentuh hancur dan halus, jika } \\
\text { diaduk agak berat. }\end{array}$ \\
\hline 4 & $\begin{array}{l}\text { Terbentuk } 12 \text { butiran kecil, jika di sentuh hancur dan halus, jika } \\
\text { diaduk agak berat. }\end{array}$ \\
\hline 6 & $\begin{array}{l}\text { Butiran menggumpal agak besar, jika disentuh hancur dan agak } \\
\text { kasar, jika diaduk agak berat. }\end{array}$ \\
\hline 8 & $\begin{array}{l}\text { Butiran menggumpal agak besar, jika diaduk agak lebih berat dan } \\
\text { tampak kasar (berbutir). }\end{array}$ \\
\hline 10 & $\begin{array}{l}\text { Butiran menggumpal lebih besar, jika diaduk agak lebih berat dan } \\
\text { tampak kasar (berbutir). }\end{array}$ \\
\hline $\begin{array}{l}\text { Pengamatan te } \\
\text { yang terjadi dilakukan } \\
2 \text { hari. Berdasarkan } \\
\text { visual terlihat bahwa }\end{array}$ & $\begin{array}{ll}\text { erhadap perubahan } & \text { secara organoleptik didefinisikan sebagai } \\
\text { dalam selang waktu } & \text { kadar air kritis. Hasil penelitian terhadap } \\
\text { pengamatan secara } & \text { perubahan fisik jelly kelor instan } \\
\text { semakin lama jelly } & \text { ditunjukkan pada Tabel 3. }\end{array}$ \\
\hline
\end{tabular}

kelor instan disimpan maka terjadi perubahan tekstur menjadi lebih kasar dan menggumpal, sehingga dapat disimpulkan bahwa tekstur (penggumpalan) merupakan atribut mutu utama dalam menentukan kerusakan produk jelly kelor instan. Menurut Indah (2011), produk kering memiliki sifat sangat sensitif terhadap perubahan nilai kadar air sehingga terjadi reaksi deteriosasi selama penyimpanan. Penyimpanan pada $\mathrm{RH}$ tinggi menimbulkan penggumpalan karena terjadinya penyerapan air oleh produk dari udara.

\section{Variabel-Variabel Pendugaan Umur Simpan Jelly Kelor Instan}

2.1 Kadar air (awal dan kadar air kritis)

Pada umumnya penurunan mutu suatu produk pangan disebabkan adanya proses kimiawi, mikrobiologis, enzimatik atau kombinasi ketiganya. Keberadaan air, khususnya air bebas diperlukan untuk membantu terjadinya proses tersebut. Kadar air pada bahan adalah kandungan air dalam suatu bahan yang dikenal dengan berat kering (dry basis) dan berat basah (wet basis).

Kadar air suatu produk pangan yang menunjukkan terjadinya kerusakan atau penurunan mutu sehingga produk mengalami penolakan oleh konsumen

Tabel 3. Kadar Air Berbagai Waktu Penyimpanan

\begin{tabular}{ccc}
\hline $\begin{array}{l}\text { Penyimpanan } \\
\text { (hari) }\end{array}$ & $\begin{array}{c}\text { Skor } \\
\text { Sensoris }\end{array}$ & $\begin{array}{c}\text { Kadar air } \\
\left(\mathrm{H}_{2} \mathrm{O} /\right. \\
\text { padatan })(\mathrm{g})\end{array}$ \\
\hline 0 & 7 & 0,1012 \\
2 & 6 & 0,1158 \\
4 & 5 & 0,1186 \\
6 & 4 & 0,1208 \\
8 & 3 & 0,1260 \\
10 & 3 & 0,1366 \\
\hline
\end{tabular}

Berdasarkan tabel 1 dapat dilihat
bahwa semakin lama penyimpanan dilakukan maka potensi kerusakan mutu terhadap kadar airnya pun semakin besar, yakni dengan persamaan linear $\mathrm{y}=0,003 \mathrm{x}$ $+0,1048$ dengan $R^{2}=0,9179$. Hal ini menunjukkan bahwa semakin lama jelly kelor instan disimpan maka teksturnya akan semakin menggumpal akibat terjadinya proses adsorpsi (penyerapan uap air dari lingkungan ke dalam bahan). 


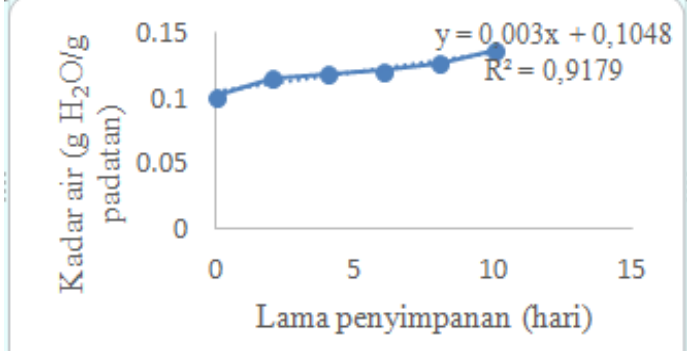

Gambar 1. Hubungan Lama Penyimpanan dan Nilai Kadar Air Jelly Kelor Instan

Pada penelitian ini untuk menentukan kadar air kritis jelly kelor instan digunakan persamaan regresi linear dari grafik hubungan antara skor sensoris dan nilai kadar air. Kadar air kritis dinyatakan pada skor penggumpalan bernilai 4 (netral) sebab mulai terbentuk gumpalan besar dalam jumlah banyak pada produk jelly kelor instan yang berarti kadar air kritis telah tercapai. Menurut Syalfina (2007), produk yang telah mencapai tingkat 'netral' maka mutunya dianggap sudah menurun dan tidak sesuai dengan mutu tekstur awalnya sehingga kondisi ini ditetapkan sebagai acuan untuk menjamin keamanan pangan.

Berdasarkan data yang diperoleh maka dibuatlah grafik diatas (Gambar 2) dan diperoleh persamaan regresi linear $\mathrm{y}=$ $-0,0066 \mathrm{x}+0,1507$ dengan nilai $\mathrm{R}^{2}=$ 0,8504 . Berdasarkan persamaan regresi diatas maka didapatkan nilai kadar air kritisnya pada saat skor rating penggumpalannya bernilai 4 , yaitu sebesar $0,1243 \mathrm{~g} \mathrm{H}_{2} \mathrm{O} / \mathrm{g}$ padatan.

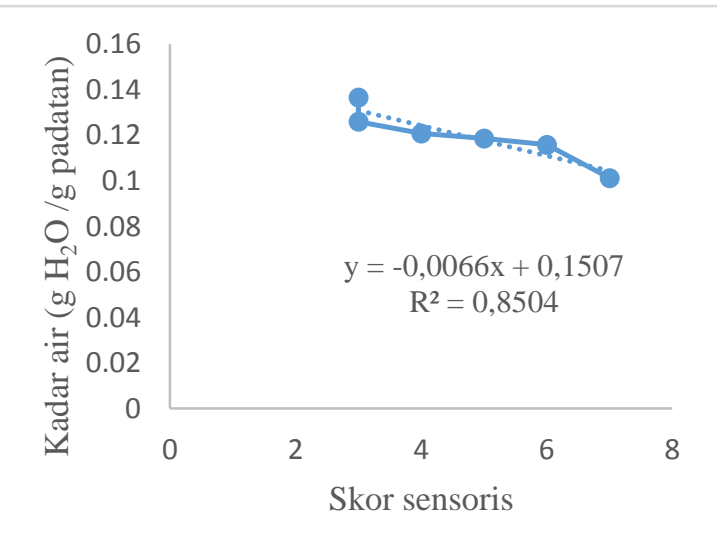

Gambar 2. Hubungan Nilai Kadar Air dengan Skor Sensoris Jelly Kelor Instan

\subsection{Kadar Air Kesetimbangan}

Selama penyimpanan sampel produk terjadi penambahan ataupun pengurangan berat yang disebut dengan fenomena karakteristik hidratasi (Syalfina, 2007). Penimbangan terhadap produk kemasan yang disimpan dalam toples modifikasi berisi larutan garam jenuh dilakukan setiap hari. Pemilihan kemasan PP ini atas dasar untuk memperkirakan waktu tercepat produk jelly kelor instan mengalami kerusakan yaitu dengan kualitas kemasan yang cukup rendah. Kemasan plastik PP memiliki sifat mempertahankan produk lebih rendah dibandingkan kemasan polietilen (PE) ataupun aluminium foil, hal ini ditunjukkan dari permeabilitas masingmasing kemasan. Kemasan dengan permeabilitas yang semakin tinggi maka akan semakin memperpendek umur simpan suatu produk. Menurut Alfiyani (2018), permeabilitas dari kemasan plastik PP adalah sebesar 0,09 $\mathrm{gH}_{2} \mathrm{O} /$ hari. $^{2}$.mmHg, dimana permeabilitas ini lebih tinggi daripada kemasan PE yaitu sebesar 0,05 $\mathrm{gH}_{2} \mathrm{O} /$ hari.m $^{2} . \mathrm{mmHg}$ dan kemasan aluminium foil yaitu sebesar 0,004 $\mathrm{gH}_{2} \mathrm{O} /$ hari.m $^{2} . \mathrm{mmHg}$ (Pratiwi, 2017). Meskipun plastik PP dengan ketebalan $0,03 \mathrm{~mm}$ ini cukup tipis, tetapi dapat meningkatkan perlindungan terhadap sobekan atau kikisan, menahan bau dan menahan gas. Selain itu, kemasan plastik memiliki harga yang relatif rendah dan mudah dibentuk sehingga dapat mengurangi biaya transportasi. Kondisi setimbang dikatakan tercapai apabila berat produk sudah konstan. Hal ini menunjukkan bahwa tekanan uap di dalam produk berada dalam kesetimbangan dengan tekanan uap lingkungan.

Pada penelitian ini digunakan 4 jenis larutan garam jenuh untuk menciptakan $\mathrm{RH}$ yang berbeda-beda, yaitu $\mathrm{NaOH}$, $\mathrm{MgCl}_{2}, \mathrm{NaCl}$, dan $\mathrm{KCl}$. Sampel yang disimpan pada larutan garam jenuh $\mathrm{NaOH}$ dan $\mathrm{MgCl}_{2}$ mengalami penurunan berat, hal ini disebabkan Aw sampel lebih tinggi daripada lingkungannya, sedangkan 
sampel yang disimpan pada larutan garam jenuh $\mathrm{NaCl}$ dan $\mathrm{KCl}$ mengalami kenaikan berat selama penyimpanan sebab Aw sampel lebih rendah daripada lingkungannya. Hal ini menunjukkan bahwa jelly kelor instan telah mengalami reaksi adsorpsi dan desorpsi uap air terhadap lingkungannya. Berikut di bawah ini adalah data kadar air kesetimbangan jelly kelor instan pada masing-masing $\mathrm{RH}$ dan waktu tercapainya kesetimbangan.

Tabel 4. Kadar Air Kesetimbangan Jelly Kelor Instan dan Waktu Tercapainya Kesetimbangan pada Berbagai RH Penyimpanan

\begin{tabular}{|c|c|c|c|}
\hline $\begin{array}{l}\text { Jenis } \\
\text { garam }\end{array}$ & $\begin{array}{c}\mathrm{RH} \\
(\% \\
)\end{array}$ & $\begin{array}{c}\text { Aktivitas } \\
\text { air }\end{array}$ & $\begin{array}{l}\text { Kadar air } \\
\left(\mathrm{g} \mathrm{H}_{2} \mathrm{O} / \mathrm{g}\right. \\
\text { padatan) }\end{array}$ \\
\hline
\end{tabular}

\begin{tabular}{ccccc}
\hline $\mathrm{NaOH}$ & 6 & 0,06 & 0,0945 & 8 \\
$\mathrm{MgCl}_{2}$ & 32 & 0,32 & 0,0985 & 9 \\
$\mathrm{NaCl}$ & 75 & 0,75 & 0,1102 & 10 \\
$\mathrm{KCl}$ & 84 & 0,84 & 0,1347 & 15 \\
\hline \multicolumn{5}{c}{ Data } \\
\multicolumn{5}{c}{ pada }
\end{tabular}

menunjukkan bahwa produk yang disimpan dengan kelembaban relatif $(\mathrm{RH})$ rendah membutuhkan waktu yang cukup singkat untuk mencapai kondisi setimbangnya. Sebaliknya, semakin tinggi nilai RH maka waktu yang dibutuhkan produk untuk mencapai kondisi setimbang semakin lama. Keadaan setimbang dihasilkan dari proses diffusi uap air yang dipengaruhi adanya selisih nilai antara kadar air awal dengan kadar ketimbangan (Indah, 2011).

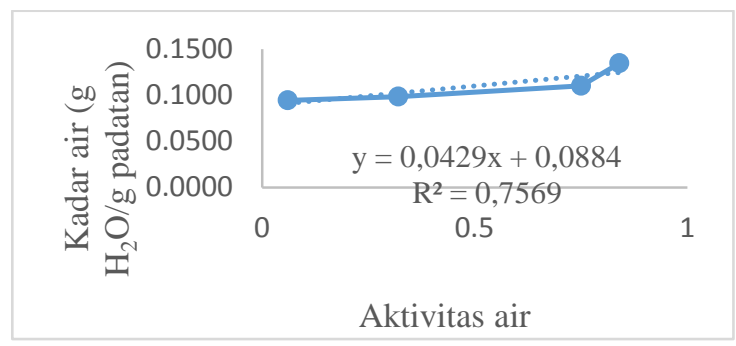

Gambar 3. Kadar Air Kesetimbangan Jelly Kelor Instan
Berdasarkan data pada Tabel 4, dibuatlah kurva sorpsi isothermis jelly kelor instan antara Aw dan berat kering seperti Gambar 3. Grafik diatas menunjukkan bahwa semakin tinggi Aw pada penyimpanan menyebabkan nilai berat keringnya akan semakin tinggi pula sehingga membutuhkan waktu yang cukup lama untuk sampai pada kondisi setimbang. Dari grafik diperoleh persamaan regresi linear $y=0,0429 x+$ 0,0884 dengan nilai $\mathbf{R}^{2}=0,7569$.

\subsection{Penentuan Slope Kurva Sorpsi Isothermis}

Kurva sorpsi isothermis adalah kurva yang menunjukkan hubungan sumbu $\mathrm{x}$ aktivitas air (Aw) dan sumbu y kadar air kesetimbangan (Me). Penentuan slope kurva sorpsi isothermis dilakukan menggunakan model matematika hasil penelitian terdahulu. Model persamaan matematika kurva sorpsi isothermis ditunjukkan pada Tabel 5.

Tabel 5. Model Persamaan Matematika Kurva Sorpsi Isothermis

\begin{tabular}{cl}
\hline Model & \multicolumn{1}{c}{ Persamaan linear } \\
\hline Hasley & $\log (\ln (1 / \mathrm{aw}))=-7,2832-$ \\
& $7,3425 \log \mathrm{Me}$ \\
Chen & $\ln (\ln (1 / \mathrm{aw}))=6,4455-$ \\
clayton & $63,05 \mathrm{Me}$ \\
Henderson & $\log (\ln (1 /(1-\mathrm{aw})))=7,5026+$ \\
& $8,091 \log \mathrm{Me}$ \\
Caurie & $\ln \mathrm{Me}=-2,4115+0,3853 \mathrm{aw}$ \\
Oswin & $\begin{array}{l}\ln \mathrm{Me}=-2,2088+0,0693 \mathrm{ln} \\
(\mathrm{aw} /(1-\mathrm{aw}))\end{array}$ \\
\hline
\end{tabular}

Tabel diatas menunjukkan beberapa model persamaan yang selanjutnya dilakukan uji ketepatan dan perhitungan terhadap nilai mean relative determination (MRD). Pengujian ketepatan dilakukan pada masing-masing model sehingga diperoleh nilai MRD yang digunakan untuk menentukan kurva sorpsi isothermis yang tepat. Penentuan masing-masing model persamaan dapat dilihat di lampiran 3 sampai dengan lampiran 7 , sedangkan untuk hasil perhitungan nilai MRD produk jelly kelor instan dari beberapa model 
persamaan sorpsi isothermis ditujukkan pada Tabel 6.

Tabel 6. Hasil Perhitungan Nilai MRD

\begin{tabular}{ll}
\hline Model & MRD \\
\hline Hasley & 5,391 \\
Chen Clayton & 6,276 \\
Henderson & 8,776 \\
Caurie & 5,657 \\
Oswin & 6,466 \\
\hline
\end{tabular}

Berdasarkan hasil perhitungan nilai MRD pada Tabel 6 diatas, model persamaan dengan tingkat keakuratan tertinggi untuk menggambarkan kurva sorpsi isothermis jelly kelor instan adalah model persamaan Hasley. Hal ini dilihat dari rendahnya nilai MRD yang dihasilkan dari model persamaan Hasley dibanding model-model persamaan lainnya yaitu sebesar 5,391. Nilai MRD dari model persamaan Hasley tersebut dapat menggambarkan keseluruhan kurva sorpsi isothermis jelly kelor instan dengan cukup tepat $(5<\mathrm{MRD}<10)$. Hasil kurva sorpsi isothermis yang diperoleh dari persamaan Hasley dapat dilihat pada Gambar 4.

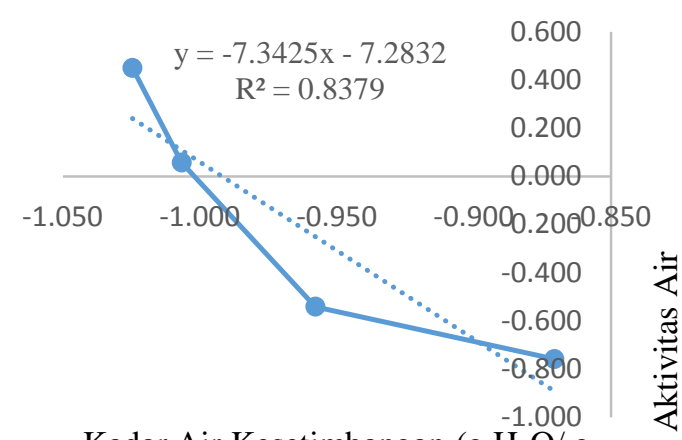

Kadar Air Kesetimbangan $\left(\mathrm{g} \mathrm{H}_{2} \mathrm{O} / \mathrm{g}\right.$ padatan)

Gambar 4. Kurva Sorpsi Isothermis Jelly Kelor Instan

Data penelitian menunjukkan bahwa kurva sorpsi isothermis jelly kelor instan memiliki persamaan $\mathrm{y}=-7,3425 \mathrm{x}-7,2832$ dengan nilai $\mathrm{R}^{2}=0,8379$. Persamaan linier ini selanjutnya akan digunakan sebagai slope (b) dalam menghitung pendugaan umur simpan jelly kelor instan.
4.4 Pendugaan Umur Simpan Jelly Kelor Instan

Umur simpan ditentukan melalui pendugaan dengan mengaplikasikan metode pendekatan kadar air kritis termodifikasi dengan dihasilkan dari perhitungan menggunakan persamaan Labuza (1982). Beberapa variabel yang digunakan dalam menentuan umur simpan produk jelly kelor yaitu menggunakan metode pendekatan kadar air kritis yaitu Mi (kadar awal), kadar air kesetimbangan (Me), kadar air kritis (Mc), luas permukaan kemasan (A), permeabilitas kemasan $(\mathrm{k} / \mathrm{x})$, tekanan uap air murni (Po), bobot padatan perkemasan (Ws), serta slope (b) kurva sorpsi isothermis. Pada penelitian ini, perhitungan umur simpan dilakukan dengan asumsi kondisi penyimpanan suhu ruang yaitu $25^{\circ} \mathrm{C}, 27^{\circ} \mathrm{C}$ dan $30^{\circ} \mathrm{C}$ dengan $\mathrm{RH}$ berkisar $61 \%$.

Alfiyani (2018) menjelaskan bahwa permeabilitas untuk kemasan PP $0,03 \mathrm{~mm}$ pada rentang RH antara 51 - 90\% berkisar antara 0,0865 - $0891 \mathrm{~g} / \mathrm{m}^{2}$.hari.mmHg. Pada kemasan produk pangan yang terbuat dari polimer hidrofobik, uap air yang bertransmisi melalui kemasan tidak berinteraksi dengan gugus hidroksi (-OH) yang berasal dari molekul penyusun kemasan. Sehingga jumlah uap air di udara yang dinyatakan sebagai nilai $\mathrm{RH}$ atau kelembaban relatif lingkungan, tidak mempengaruhi permeabilitas kemasan yang tersusun dari polimer hidrofobik. Dengan demikian, berat kemasan (yang berisi silika gel) ketika ditimbang merupakan berat kemasan, ditambah berat silika gel yang menyerap uap air dari lingkungan.

Data-data berdasarkan variabel pendugaan umur simpan yang telah didapatkan selanjutnya dihitung menggunakan persamaan Labuza. Perhitungan umur simpan simpan jelly kelor instan secara lengkap dapat dilihat pada Lampiran 10, dan hasil perhitungan umur simpan jelly kelor instan ditunjukkan pada Tabel 7. 
Berdasarkan hasil variabel umur simpan tersebut diperoleh hasil bahwa jelly kelor instan dengan penyimpanan pada suhu ruang dan RH $61 \%$ dan dikemas dalam plastik PP $0,03 \mathrm{~mm}$ memiliki umur simpan berkisar 589 - 789 hari atau 19 26 bulan. Hasil pendugaan umur simpan tersebut dapat digunakan produsen jelly kelor instan untuk menentukan tanggal kadaluarsa produk pada kemasan tergantung kebijakan produsen. Menurut Syalfina (2007), pada umunya perusahaan mencantumkan tanggal kadaluarsa lebih awal 2-3 bulan bahkan 6 bulan untuk memberikan keleluasaan waktu untuk keperluan distribusi produk ke pasaran dan menarik kembali produk dari pasaran sebelum masa kadaluarsanya habis.

Pada bumbu instan bubuk yang disimpan dalam kondisi penyimpanan $38^{\circ} \mathrm{C}$ dan $\mathrm{RH} 75 \%$ dengan kemasan plastik High Density Polyethylene (HDPE) yang diikat dengan kabel ties, lalu dilapisi oleh plastik Linear Low Density Polyethylene (LLDPE) yang diikat dengan kabel ties, kemudian dimasukkan dalam dus karton berbahan pulp memiliki umur berkisar antara 125 hari (4 bulan) sampai 432 hari (14 bulan) (Kosasih, 2018). Pratiwi (2017) menyebutkan bahwa pada penyimpanan suhu $28^{\circ} \mathrm{C}$, umur simpan minuman bubuk cokelat instan dengan kemasan metalizing ketebalan 51,89 $\mu \mathrm{m}$ mencapai 16,39 bulan. Faridah et al. (2013) menjelaskan bahwa umur simpan untuk produk bandrek instan dapat mencapai 341 hari (11 bulan) apabila dikemas dalam flexible aluminized film dengan RH $80 \%$ dan suhu $30^{\circ} \mathrm{C}$.

Apabila dibandingkan produk sejenis yang ditentukan dengan metode kadar air kritis, seperti bumbu instan bubuk, minuman bubuk cokelat Chocomix, dan bandrek instan, maka umur simpan jelly kelor instan memiliki umur simpan lebih panjang, dan tidak lebih pendek dibanding produk kopi instan formula dan minuman instan temulawak. kopi instan formula yang disimpan pada suhu penyimpanan $30^{\circ} \mathrm{C}$ RH $70 \%$ memiliki umur simpan adalah 632 hari (21 bulan) dengan bahan kemasan metalized plastics (Wijaya, 2007). Kusuma (2015) melaporkan bahwa minuman instan temulawak memiliki umur simpan selama 1197,4 hari pada kemasan PP 0,03 mm; 1475,7 hari pada kemasan PP $0,05 \mathrm{~mm}$ dan 1013,5 hari pada kemasan PE $0,03 \mathrm{~mm}$ berturut. Perbedaan umur simpan pada tiap produk ini dipengaruhi beberapa faktor, yaitu perbedaan kemasan yang digunakan, komposisi produk yang berbeda serta kondisi penyimpanan yang berbeda pula.

Tabel 7. Pendugaan Umur Simpan Produk Jelly Kelor Instan

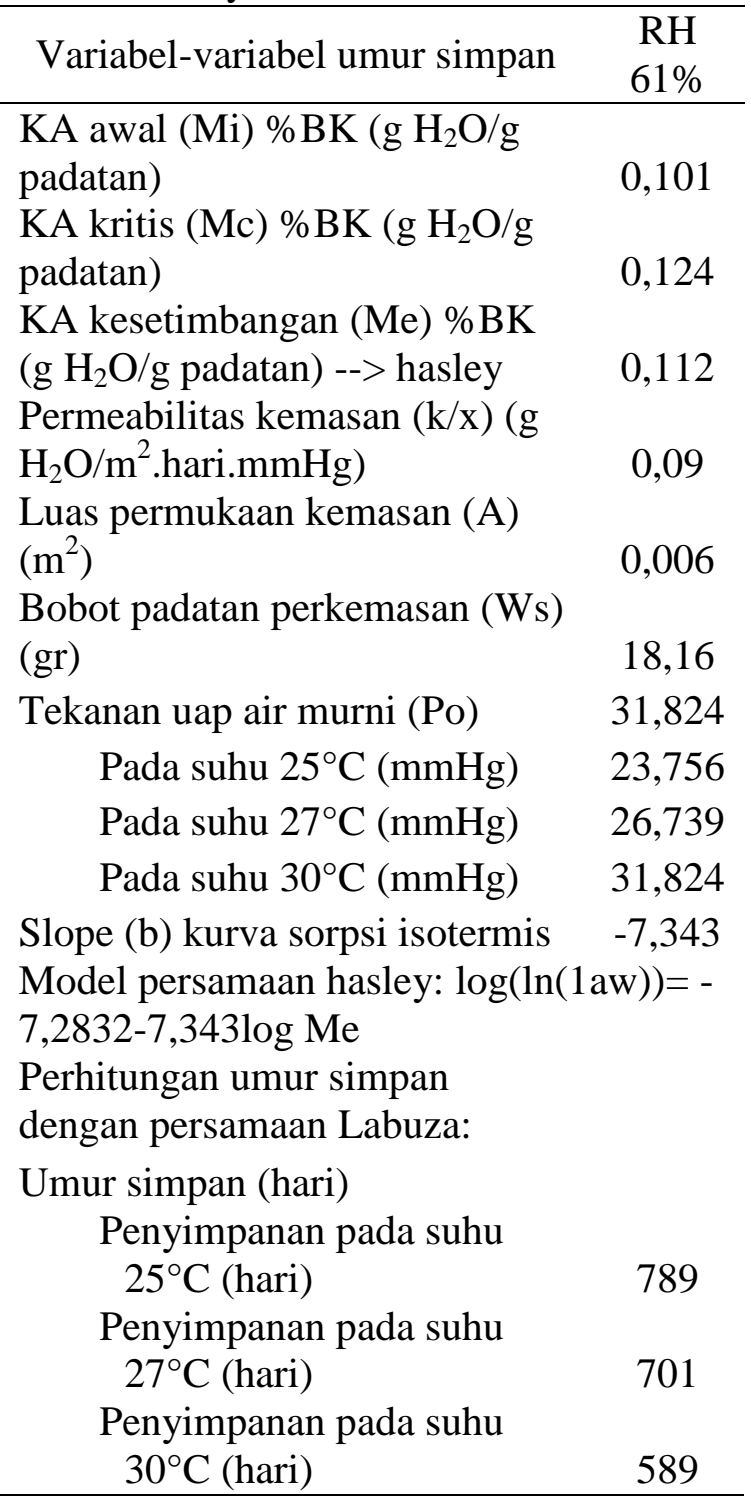

\section{KESIMPULAN}

Produk jelly kelor instan dengan kemasan plastik PP 0,03 mm dan disimpan pada RH $61 \%$ dan suhu ruang yaitu $25^{\circ} \mathrm{C}$, 
$27^{\circ} \mathrm{C}$ dan $30^{\circ} \mathrm{C}$ secara berturut-turut memiliki umur simpan berkisar 789 hari, 701 hari dan 589 hari. Jelly kelor instan yang telah melewati umur simpannya akan mengalami penurunan sifat sensoris. Hal ini dapat diamati secara visual yaitu akan mengalami penggumpalan.

\section{DAFTAR PUSTAKA}

Alfiyani, N. 2018. Penetapan Parameter Kurva ISA dalam Penentuan Umur Simpan Produk Pangan Kering Metode Kadar Air. Bogor: Institut Pertanian Bogor.

Anom, M. dan Komang. 2008. Penentuan Masa Kadarluarsa Rengginang dengan Menggunakan Model Labuza. Jurnal Agrotekno Vol. 14 (1).

Arpah. 2001. Penetapan Kadaluwarsa Produk Pangan. Departemen Teknologi Pangan dan Gizi. Fakultas Teknologi Pertanian. Bogor: Institut Pertanian Bogor.

Faridah, D.N., S. Yasni, A. Suswantinah dan G.W. Aryani. 2013. Pendugaan Umur Simpan dengan Metode Accelerated Shel-Life Testing Pada Produk Bandrek Instan dan Sirup Buah Pala (Myristica fragnans). Jurnal Ilmu Pertanian Indonesia Vol. 18 (3): 144-153.

Hasany, M.R., E. Afrianto dan R.I. Pratama. 2017. Pendugaan Umur Simpan Menggunakan Metode Accelerated Shelf Life Test (ASLT) Model Arrhenius pada Fruit Nori. Universitas Padjajaran. Jurnal Perikanan dan Ilmu Kelautan Vol. 8 (1): 48-55.

Indah, H.D. 2011. Pendugaan Umur Simpan Produk Cone Es Krim dengan Metode Akselerasi Model Kadar Air Kritis. Bogor: Institut Pertanian Bogor.

Kosasih, A.H.M. 2018. Pendugaan Umur Simpan Produk Bumbu Instan Bubuk dengan Pendekatan Kadar Air Kritis. Bogor: Institut Pertanian Bogor.
Krisnadi, A.D. 2015. Kelor Super Nutrisi.

Blora: Pusat Informasi dan Pengembangan Tanaman Kelor Indonesia.

Kusuma, N.W. 2015. Pendugaan Umur Simpan Minuman Instan Temulawak (Curcuma xanthorrhiza roxb.) menggunakan Metode Accelerated Shelf Life Test (ASLT) Pendekatan Isotherm Sorpsi Lembab (ISL). Surakarta: Universitas Sebelas Maret.

Labuza, T.P. 1982. Shelf Life Dating of Foods. Food and Nutrition Press, Inc. Westport, Connecticut.

Ningulan, A.C. 2018. Pengaruh Penambahan Tepung Daun Kelor dan Bahan Pengejel terhadap Sifat Fisik dan Kimia Jelly Kelor Instan. Tugas Akhir. Jember: Politeknik Negeri Jember.

Puji, W. dan Arpah. 2003. Penetapan Kadarluarsa Produk Industri Kecil Pangan. Departemen Teknologi Pangan dan Gizi Fakultas Teknologi Pertanian. Bogor: Institut Pertanian Bogor.

Pratiwi, L.D. 2017. Pendugaan Umur Simpan Cookies Sumbe Protein dan Energi dari Tepung Campuran Berbasis Mocaf dengan Variasi Kemasan. Surakarta: Universitas Sebelas Maret.

Pratiwi, R. 2017. Pendugaan Umur Simpan Produk Minum Bubuk Cokelat Instan Chocomix dengan Metode Accelerated Shelf-Life Testing (ASLT) Pendekatan Kadar Air Kritis. Surakarta: Universitar Sebelas Maret.

Prihayati, I.N., Y. Purnamawati, A. Sophiani, N. Muis, Rachmawati, F. Amri dan R. Mutia. 2014. Potensi tepung daun kelor (Moringa oleifera lamk) sebagai suplemen beta karoten untuk menghasilkan telur puyuh yang kaya antioksidan. Laporan Akhir. Bogor: Institut Pertanian Bogor. 
Saptyasih, A.R.N., L. Widajanti dan S.A. Nugraheni. 2016. Hubungan Asupan Zat Besi, Asam Folat, Vitamin B12 dan Vitamin $C$ dengan Kadar Hemoglobin Siswa di SMP Negeri 2 Tawangharjo Kabupaten Grobongan. Jurnal Kesehatan Masyarakat Vol. 4 (4)

Simbolan, J.M., M. Sitorus dan N. Katharina. 2007. Cegah Malnutrisi dengan Kelor. Yogyakarta: Kanisius.

Syalfina, M. 2007. Pendugaan Umur Simpan Permen Jahe dengan Menggunakan Metode Accelerated Shelf Life Testing (ASLT) dengan Pendekatan Model Kadar Air Kritis. Bogor: Institut Pertanian Bogor.

Tangkilisan, H.A dan D. Rumbajan. 2002. Defisiensi Asam Folat. http://www.researchgate.net/publicat ion/312198953_Defisiensi_Asam_Fo $\underline{\text { lat }}$ [Diakses pada 13 September 2019].

Wijaya, C. H. 2007. Pendugaan Umur Simpan Produk Kopi Instan Formula Merk-Z dengan Metode Arrhenius. Bogor: Institut Pertanian Bogor. 